of environment, as they at present exist, are against such abnormal development. If, during the past, no such recognizable pale race has been produced by the conditions as claimed and presented, what ground or promise is there of now establishing such a race amidst a shooting club, a life saving station, and fishermen who have numbers of cats to hold in check the vermin. These vermin are the direct result of those reintroduced on the island by Mr. Miller and associates several years ago.

I fail to appreciate and dissent from the statement near the foot of page 77 that, "by helping to offer direct historical proof of the rapidity at which modification may progress under natural conditions the Terns would be fulfilling a more important end than in gladdening the eye of the visitor to Muskeget, and the heart of the reader of Mr. Mackay's progress report." These beautiful birds are fulfilling at the present time a much more important end than the one suggested, by delighting the eye of every lover of bird life to whom the privilege of enjoying their companionship is given. Refining in their influences, what higher or better end can they serve?

George H. Mackay,

Boston, January I 7, I898.

\title{
The Short-eared Owls of Muskeget Island.
}

\section{Editors of 'THE AUK':-}

Dear Sirs:- I quite agree with Mr. Miller ( $c f$. Auk, XV, No. I, January, 1898 , pp. $75^{-77}$ ) that the killing of the family of Muskeget Owls in I 896 , merely because they were preying on the Terns, was ill-judged. If Muskeget were my private property I should encourage and protect the Owls, and they would be made welcome to as many Terns as they chose to eat, for I should feel confident that however fast they might increase the Terns would outsirip them in the race. As Mr. Miller says, bird protection should not be made one sided for if it be so it is certain to lose not only its scientific but much of its aesthetic value, as well as something, even, of its practical usefulness. Bird protectors, whether they be sportsmen or pure bird lovers, would do well to study more closely the balance of nature, for it concerns the success of their enterprises far more closely than they seem to realize. Even the naturalists do not as yet fully understand the complex workings and delicate adjustments of a system which, when not interfered with by man, seems invariably to result in the production and maintenance of the richest possible fauna, of which the predatory and non-predatory forms increase together to the full limits of the capacity for food and shelter which the country furnishes. No one who has ever visited a primitive region, well timbered, well watered and not too cold, can deny the truth of this, but it is certainly difficult to understand or explain how Hawks, Owls, Herons, 
Kingfishers and the various carnivorous mammals can exist, as they so often do, in the greatest abundance without exterminating the defenseless creatures on which they prey.

Mr. Miller, however, bases his protest on the assumption that "a recognizable race" of the Short-eared Owl formerly existed on Muskeget, and that the birds which Mr. Mackay caused to be destroyed might have reproduced a similarly interesting form had they been left unmolested. In support of the former assertion he refers to Mr. Maynard's statement (Birds of Eastern N. Am., I 88 I, p. 264) that some specimens taken there in July, 1870 were so "bleached as to appear nearly white in the distance" adding that "of course, at so early a period in the summer, this bleaching could hardly have been due to a mechanically abraded condition of the plumage, and indeed Mr. Maynard has personally assured me that such was not the case, but that the birds represented a pale, resident race."

I had the pleasure of accompanying Mr. Maynard to Muskeget in 1870 , and my notes relating to our mutual experience state that but four Shorteared Owls were seen, and that all of these were shot. Three of the skins fell to my share when the spoils of the trip were divided, and are still in $\mathrm{my}$ collection. A male and female killed June 30 are, as Mr. Maynard says, very pale in general coloring but the third bird, a female taken July 2 , is much darker. The plumage of all three birds is excessively ragged, many of the feathers having lost, by abrasion, nearly or quite one half of their normal area, while some of them are worn away almost to the shaft. But even the lighter two birds have a number of scapulars and interscapulars which are perfect in outline and which are not only much darker than the worn portions of the plumage, but nearly or quite as dark as corresponding feathers of birds taken in autumn or winter at places hundreds or even thousands of miles distant from Muskeget. These feathers may have been of recent growth at the time when the birds were killed but it is more probable that they were old feathers which had been protected by the overlapping plumage from the bleaching and disintegrating effects of the air and sunlight, for the inner quills, as well as the inner webs of the outer primaries and tail-feathers, are almost equally fresh and perfect, in striking contrast with the frayed and bleached outer portions of some of the wing and tail-feathers.

It is, of course, quite safe to assert that at some time earlier in the season the general coloring of these birds must have been not unlike that which the unworn parts of the plumage now exhibit, and it seems not unreasonable to assume that even these unworn feathers must have lost something of their original depth and richness of tint. If this be granted, and a very slight allowance made for fading, I do not see how it can be maintained that the Short-eared Owls taken by Mr. Maynard and myself on Muskeget Island in $I 870$ were in any respects peculiar. Even if the allowance for fading be not conceded it is quite possible, as I have already stated, to match the unworn feathers by corresponding feathers 
on light-colored birds taken during the migrations in other parts of New England and elsewhere. It follows as a matter of course that there is no evidence, historical or otherwise, that Muskeget has ever harbored a "recognizable local race" of the Short-eared Owl. It would be indeed remarkable had such been the case, for the food resources of the island, excepting during the brief season when the Terns are breeding there, are not sufficient to supply the wants of more than two or three families of Owls, and a local race which at no one period of its existence could have been represented by more than a score of individuals would be something of an anomaly.

In this connection it may be worth remarking (since the fact seems to have been generally overlooked by American ornithologists) that there is a very decided and constant difference in coloring between the sexes of the Short-eared Owl, the males, when in fully adult plumage, being very much lighter-colored than the females. I have several males taken during the migrations at Ipswich, Massachusetts, as well as from the Pacific Coast, which are almost as pale as the Muskeget birds, and there is not a single fully adult male in my large series which is as dark as the average female. Dresser, in his 'Birds of Europe' (V, p. $25^{8}$ ), states that the same sexual difference is found in Old World representatives of the Shorteared Owl.

Very truly yours,

William Brewster.

Cambridge, Mass.

March, I 898 .

\section{An Untrustworthy Observer.}

\section{Editors of 'The AuK':-}

Dear Sirs:- Those members of the A. O. U. who were present at the meeting last November will doubtless recall a paper read by Mr. Edwin Irvine Haines entitled 'The Summer Birds of the Catskill Mountains with remarks upon the Faunæ of the Region.' The paper indicated a ' chumminess' on the part of the birds that enabled the writer to fairly rain down records of species that ordinarily, during the summer season, are satisfied to keep out of the Catskills. Several sets of eggs of the Solitary Sandpiper (Totanus solitarius), Canada Jay (Perisoreus canadensis), and Ipswich Sparrow (Ammodramus princeps) had been obtained, while such species as the Hudsonian Chickadee (Parus hudsonicus) and Whitecrowned Sparrow (Zonotrichia albicollis) had been found hobnobbing with the equally abundant Dickcissel (Spiza americana) and Tufted Titmouse (Parus bicolor). A tray full of skins, chiefly without labels and in winter plumage, was exhibited in support of the many extraordinary discoveries of which the above are samples. On asking Mr. Haines for 


\section{$2 \mathrm{BHL}$ Biodiversity Heritage Library}

Brewster, William. 1898. "The Short-Eared Owls of Muskeget Island." The Auk 15, 211-213. https://doi.org/10.2307/4068279.

View This Item Online: $\underline{\text { https://www.biodiversitylibrary.org/item/87802 }}$

DOI: https://doi.org/10.2307/4068279

Permalink: https://www.biodiversitylibrary.org/partpdf/88853

\section{Holding Institution}

Harvard University, Museum of Comparative Zoology, Ernst Mayr Library

\section{Sponsored by}

Harvard University, Museum of Comparative Zoology, Ernst Mayr Library

\section{Copyright \& Reuse}

Copyright Status: Public domain. The BHL considers that this work is no longer under copyright protection.

This document was created from content at the Biodiversity Heritage Library, the world's largest open access digital library for biodiversity literature and archives. Visit BHL at https://www.biodiversitylibrary.org. 